\title{
The Effect of $p$-Fluorophenylalanine on the Replication of Rabbitpox Virus and its Nucleic Acid
}

\author{
By G. APPLEYARD AND H. T. ZWARTOUW \\ Microbiological Research Establishment, Porton, Wiltshire
}

(Received 8 October 1964)

SUMMARY

The multiplication of rabbitpox virus in HeLa (ERK) cells was inhibited by $p$-fluorophenylalanine (FPA) $400 \mu \mathrm{g} . / \mathrm{ml}$. When added early in the growth cycle, FPA prevented the formation of viral DNA. The FPA-sensitive process necessary for DNA synthesis began about $1 \frac{1}{4} \mathrm{hr}$ after infection. This was at least $1 \mathrm{hr}$ before the first development of viral DNA, but coincided with the time of synthesis of the earliest viral antigens. On the basis of this and other evidence, it is suggested that some soluble viral antigens are enzymes concerned in the synthesis of viral DNA.

\section{INTRODUCTION}

When rabbitpox virus multiplies in HeLa (ERK) cells, virus maturation is preceded by the synthesis of viral DNA and of viral antigens (Appleyard \& Westwood, 1964). DNA synthesis begins $2 \frac{1}{2} \mathrm{hr}$ after infection, which is $2 \frac{1}{2} \mathrm{hr}$ before the first appearance of new virus. The numerous soluble antigens are formed at various stages of growth; some of them cannot be detected until after the start of virus maturation, whereas others appear only $1-1 \frac{1}{2} \mathrm{hr}$ after infection. The synthesis of viral antigens is independent of the synthesis of viral DNA, for not only are some antigens formed before DNA, but the development of all of them is unaffected by bromodeoxyuridine. In the present work we have used the compound $p$-fluorophenylalanine, which inhibits the formation of infective virus, to show that the formation of viral DNA, on the other hand, does depend upon the synthesis of protein. The time of the essential protein synthesis was measured, and related to the time of appearance of soluble viral antigens.

\section{METHODS}

The techniques used were similar to those of Appleyard \& Westwood (1964) and may be summarized briefly.

Virus. This was the Utrecht strain of rabbitpox virus, adapted to HeLa (ERK) cells.

Cell cultures. HeLa (ERK) cultures were normally used as confluent monolayers in $8 \mathrm{~cm}$. Carrel flasks. When cells were to be stained with acridine orange, semiconfluent monolayers were grown on coverslips.

Virus growth. Cell cultures in Carrel flasks were incubated for $1 \mathrm{hr}$ at $36^{\circ}$ with $2 \mathrm{ml}$. rabbitpox virus suspension of titre $10^{8}$ plaque-forming units (p.f.u.)/ml.; this 
resulted in infection of over $90 \%$ of the cells. Unadsorbed virus was removed by washing with phosphate buffered saline, then $10 \mathrm{ml}$. maintenance medium added and the incubation continued for periods up to $24 \mathrm{hr}$. All growth periods were measured from the time at which cultures were first inoculated with virus.

Virus titration. Infected cultures were harvested by scraping the cells from the glass and disrupting them by ultrasonic treatment. The virus content was titrated as plaque-forming units (p.f.u.) in HeLa (ERK) monolayers.

Detection of viral antigens. Cultures to be tested for soluble viral antigens were first concentrated to $4 \times 10^{7}$ cells $/ \mathrm{ml}$. and then disrupted ultrasonically. The resulting extract was examined by micro-immunodiffusion against hyperimmune rabbitpox serum.

Detection of viral $D N A$. Cell cultures on coverslips were infected by incubation for $1 \mathrm{hr}$ at $36^{\circ}$ with $0 \cdot 2 \mathrm{ml}$. rabbitpox virus of titre $10^{8}$ p.f.u. $/ \mathrm{ml}$. After washing, incubation was continued in maintenance medium. At different stages of virus growth, sample cultures were fixed in ethanol, stained with acridine orange, and examined under dark-ground ultraviolet illumination for green cytoplasmic inclusions.

\section{RESULTS}

\section{Effect of $p$-fluorophenylalanine on virus multiplication}

DL-p-fluorophenylalanine (FPA), at a concentration of $400 \mu \mathrm{g} . / \mathrm{ml}$. or above, completely inhibited the formation of infective virus (Fig. 1). FPA interferes with protein synthesis, either by preventing it or by becoming incorporated into protein in the place of phenylalanine (Cohen \& Munier, 1959). The synthesis of a great many proteins is likely to be necessary for the multiplication of rabbitpox virus, and it would therefore be expected that several stages of the growth cycle would be sensitive to inhibition by FPA.

To estimate the time of the last FPA-sensitive stage of growth, FPA $400 \mu \mathrm{g} . / \mathrm{ml}$. was added to a series of cultures at various times after infection, and the final virus yields titrated after incubation for $24 \mathrm{hr}$. FPA completely prevented virus replication when added as late as $\mathbf{3} \mathrm{hr}$ after infection, but a small amount of virus was produced when it was not added until $4 \mathrm{hr}$. Since, during normal growth, new virus first appeared $5 \mathrm{hr}$ after infection, it follows that the last FPA-sensitive stage of growth occurred about $1 \mathrm{hr}$ before virus maturation. This conclusion was confirmed by studying the course of virus growth in cultures to which FPA at concentrations of 400,800 or $1600 \mu \mathrm{g} . / \mathrm{ml}$. was added $6 \mathrm{hr}$ after infection. Virus increase continued for $1 \mathrm{hr}$ after the addition of each of these concentrations of inhibitor, and then ceased abruptly.

The inhibition caused by FPA was annulled by its removal and replacement with normal medium. This made it possible to time the earliest stage at which FPA acted on virus growth. One-step growth experiments were made in normal cell cultures and in cultures to which FPA $400 \mu \mathrm{g} . / \mathrm{ml}$. was added for the first $2 \mathrm{hr}$ or $4 \mathrm{hr}$ after infection (Fig. 2). The exposure of cultures to FPA for $2 \mathrm{hr}$ delayed growth by only about $\frac{1}{2} \mathrm{hr}$ and exposure for $4 \mathrm{hr}$ caused a delay of about $3 \mathrm{hr}$. The first FPA-sensitive stage in virus growth therefore began $1-1 \frac{1}{2} \mathrm{hr}$ after infection. 


\section{Effect on the synthesis of viral antigens}

Infected cultures were incubated for $24 \mathrm{hr}$ either in normal medium or in medium containing FPA at concentrations up to $1600 \mu \mathrm{g} . / \mathrm{ml}$. The yields of virus from these cultures are shown by the triangles in Fig. 1. Examination of cell extracts by immunodiffusion showed that the lowest concentration of FPA that completely inhibited infective virus production $(400 \mu \mathrm{g} . / \mathrm{ml}$.) had only a very slight effect on the synthesis of soluble antigens. Higher concentrations did prevent the formation of

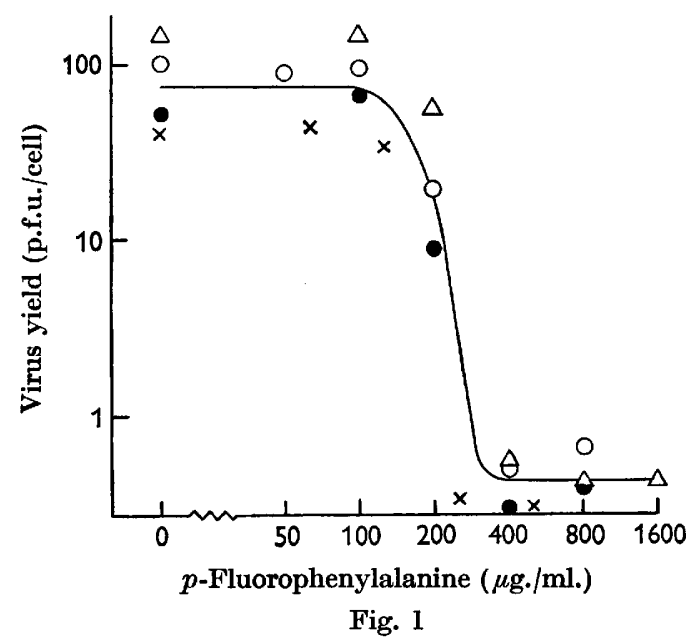

Fig. 1

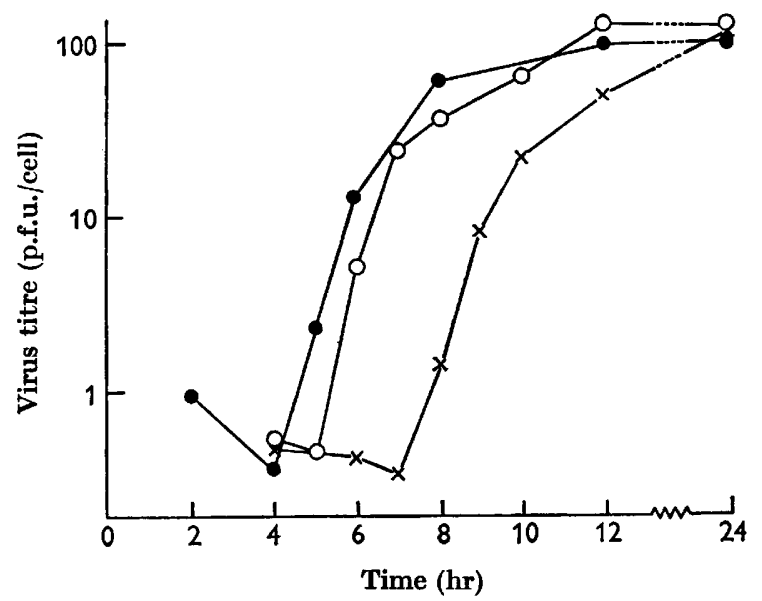

Fig. 2

Fig. 1. Effect of $p$-fluorophenylalanine (FPA) on the $24 \mathrm{hr}$ yield of rabbitpox virus from HeLa (ERK) cultures. The symbols represent the results of four different experiments.

Fig. 2. Growth of rabbitpox virus after temporary exposure of infected cultures to FPA. , normal growth; $O$, growth after exposure to FPA for first $2 \mathrm{hr}$ after infection; $x$, growth after exposure to FPA for first $4 \mathrm{hr}$ after infection.

many antigens, but at least six antigens were produced even in the presence of FPA $1600 \mu \mathrm{g} . / \mathrm{ml}$; the yield of a few antigens was increased by FPA at concentrations of $400 \mu \mathrm{g} . / \mathrm{ml}$. and above. Since FPA is known to inhibit a stage of growth that occurs within $1 \frac{1}{2} \mathrm{hr}$ of infection, its effect on the synthesis of the early viral antigens was tested. Virus was grown for only $2 \mathrm{hr}$ in the presence or absence of FPA $400 \mu \mathrm{g}$./ ml., and the cell extracts were then examined by immunodiffusion. Identical patterns of nine precipitin lines were produced by the antigens from both control and inhibited cultures.

\section{Effect on the formation of viral nucleic acid}

Experiments with acridine orange. During normal virus growth (Appleyard \& Westwood, 1964), the staining of cultures with acridine orange showed multiple small foci of DNA in the cytoplasm of a few cells $2 \frac{1}{2} \mathrm{hr}$ after infection, and within another $2 \mathrm{hr}$ almost all the cells developed DNA. The foci steadily increased in size, began to spread and fragment about $6 \mathrm{hr}$ after infection, and by $24 \mathrm{hr}$ DNA was diffused widely through the cytoplasm. To investigate the effect of FPA on the formation of viral DNA, infected cell cultures on coverslips were incubated in 
medium with or without FPA $400 \mu \mathrm{g} . / \mathrm{ml}$. Sample cultures were stained with acridine orange at 5,8 and $24 \mathrm{hr}$. The control cultures showed the normal development of viral DNA. But the cells of inhibited cultures contained no cytoplasmic DNA at $5 \mathrm{hr}$ or $8 \mathrm{hr}$ and only a few very small localized foci at $24 \mathrm{hr}$. Other experiments gave similar results, except that the cells of inhibited cultures sometimes showed a few minute DNA inclusions at $8 \mathrm{hr}$.

The effect of adding FPA at different times in the virus growth cycle was then studied. A series of cultures on coverslips was infected in the usual way, and FPA $400 \mu \mathrm{g} . / \mathrm{ml}$. was added either with the virus or at various times up to $4 \mathrm{hr}$ after infection. Cultures were stained with acridine orange $7 \mathrm{hr}$ after infection, the cells containing DNA were counted and the appearance of the foci noted. In addition, the course of DNA development was followed at hourly intervals in uninhibited cultures and in cultures to which FPA was added at $2 \mathrm{hr}$ (Fig. 3). It was found that the addition of FPA either with the virus or $1 \mathrm{hr}$ after infection almost completely suppressed DNA formation, the cells that did contain DNA at $7 \mathrm{hr}$ having only a

Table 1. Inhibition of the growth of rabbitpox virus by p-fluorophenylalanine (FPA) followed by bromodeoxyuridine (BDU)

Treatment of culture

None

BDU (20 $\mu \mathrm{g} . / \mathrm{ml}$.$) 8-24 hr$

FPA $(400 \mu \mathrm{g} . / \mathrm{ml}$.) $0-8 \mathrm{hr}$

FPA 0-8 hr + BDU 8-24 hr

$$
\begin{gathered}
\text { Virus yield } \\
\text { at } 24 \mathrm{hr} \\
\text { (p.f.u./cell) }
\end{gathered}
$$

87
73
124
$0 \cdot 42$

few very small inclusions. But FPA added $2 \mathrm{hr}$ after the virus only partially inhibited DNA synthesis, and when added at $3 \mathrm{hr}$ or $4 \mathrm{hr}$ it was even less effective. These results indicated that an FPA-sensitive process was essential for the synthesis of viral DNA, and that this process began between $1 \mathrm{hr}$ and $2 \mathrm{hr}$ after virus infection.

Experiments with bromodeoxyuridine. The multiplication of rabbitpox virus was inhibited by bromodeoxyuridine (BDU) $20 \mu \mathrm{g} . / \mathrm{ml}$. (Appleyard \& Westwood, 1964). Inhibition was caused by the incorporation into viral DNA of BDU in the place of thymidine, thus producing non-functional nucleic acid. The course of viral DNA synthesis could be studied by measuring the final yields of virus from a series of cultures to which BDU had been added at different times after infection. Under normal circumstances, BDU caused little decrease in the final virus yield when added $8 \mathrm{hr}$ after infection of a culture, for almost all the viral DNA had already been synthesized by this time. However, when FPA was included in the medium for the first $8 \mathrm{hr}$, then the addition of BDU at this time resulted in complete inhibition of virus growth (Table 1). Temporary exposure to FPA did not itself decrease the virus yield; on the contrary there was a slight increase, which was frequently observed when FPA was added to cultures at the time of infection and later removed.

This result showed that FPA prevented the synthesis of viral DNA. In order to time the FPA-sensitive step in DNA synthesis, the same type of experiment was repeated except that FPA was added to cultures at progressively later times after infection. The final virus yields obtained when FPA was added at different times and then replaced at $8 \mathrm{hr}$ with medium containing BDU are shown in Fig. 4, curve 
C. For comparison, curve $A$ of this figure is a normal virus growth curve, and curve B shows the course of viral DNA synthesis obtained by titrating the $24 \mathrm{hr}$ yields of virus after addition of BDU at the times indicated. It can be seen from curve $C$ that FPA completely prevented DNA synthesis when added either with the virus or $1 \mathrm{hr}$ later, but by $2 \mathrm{hr}$ after infection the cultures were beginning to pass the sensitive stage of growth. The unexpectedly low yield of virus from the cultures to which FPA was added at $4 \mathbf{h r}$ or later was a usual occurrence. Temporary exposure of cultures to FPA between $4 \mathrm{hr}$ and $8 \mathrm{hr}$ after infection decreased the virus yield even without subsequent treatment with BDU.

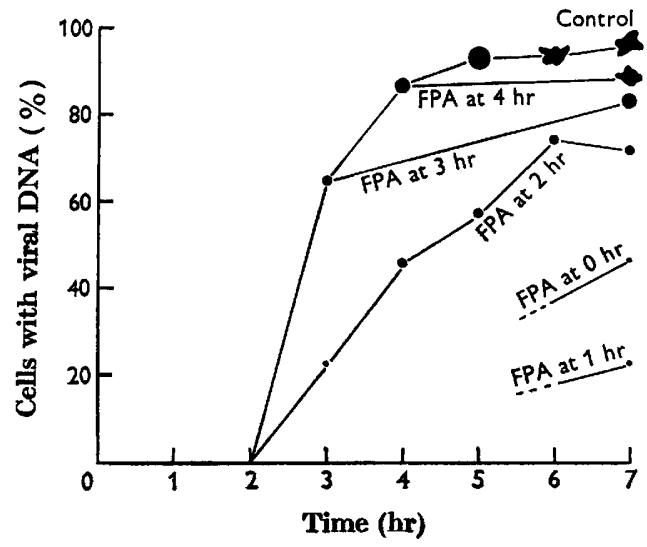

Fig. 3

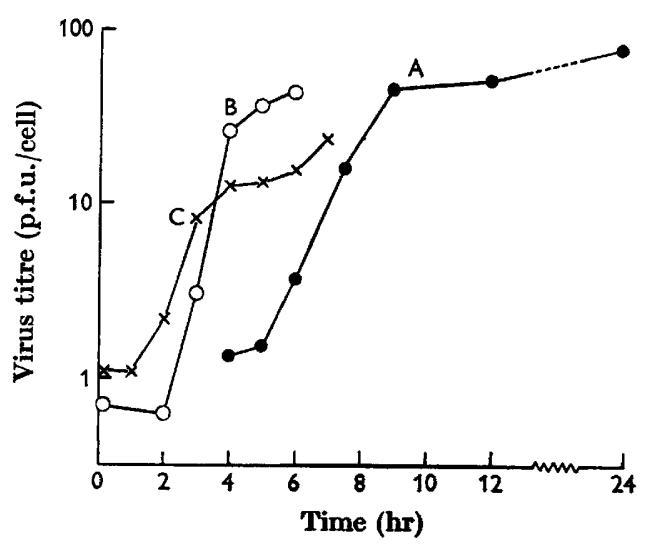

Fig. 4

Fig. 8. Effect of time of addition of FPA on its ability to inhibit the formation of DNA inclusions by infected cultures. The \% cells containing inclusions were counted at the times shown. The size of each symbol is proportional to that of the typical inclusions in a particular culture, and its shape indicates whether the inclusions were compact or spreading.

Fig. 4. Effect of time of addition of FPA on its ability to inhibit the synthesis of viral DNA by infected cultures. $O$, virus growth curve; $O$, curve of DNA formation, obtained by titrating the virus yield at $24 \mathrm{hr}$ from cultures to which bromodeoxyuridine (BDU) was added at the times shown; $x$, virus yield at $24 \mathrm{hr}$ after addition of FPA at times shown followed at $8 \mathrm{hr}$ by removal of FPA and addition of BDU.

Fig. 5 shows the results of a similar experiment designed to determine more precisely the time at which the FPA-sensitive process began. The three curves were obtained as before, but observations were made more frequently and confined to the early period of growth. If a level of 1 p.f.u./cell is arbitrarily taken as the first significant rise in titre, then virus maturation began at about $5 \mathrm{hr}$, DNA formation at about $2 \mathrm{hr} 40 \mathrm{~min}$., and the FPA-sensitive reaction at about $1 \mathrm{hr} 15 \mathrm{~min}$.

The start of the FPA-sensitive step in DNA synthesis could also be timed by measuring the delay in DNA synthesis caused by the temporary exposure of infected cultures to FPA. In the experiment illustrated in Fig. 6, four groups of cultures were infected with rabbitpox virus. The control group was incubated without FPA, whereas the other three were treated with FPA $400 \mu \mathrm{g}$. $/ \mathrm{ml}$. for the first 1,2 or $3 \mathrm{hr}$ of incubation. DNA formation was followed during the early stages of virus growth by titrating the final virus yields from cultures to which BDU was added at different times. When, as before, a value of 1 virus equivalent/cell is taken as the first 
significant increase in DNA, then DNA synthesis began at about $2 \mathrm{hr} 35 \mathrm{~min}$. in the control cultures. Synthesis was unaffected by the presence of FPA for the first $1 \mathrm{hr}$ after infection; but exposure for $2 \mathrm{hr}$ or $3 \mathrm{hr}$ delayed the first appearance of DNA until about $3 \mathrm{hr} 25 \mathrm{~min}$ or $4 \mathrm{hr} 20 \mathrm{~min}$., respectively. This indicated that the FPAsensitive step began about $1 \mathrm{hr} 15 \mathrm{~min}$. after infection.

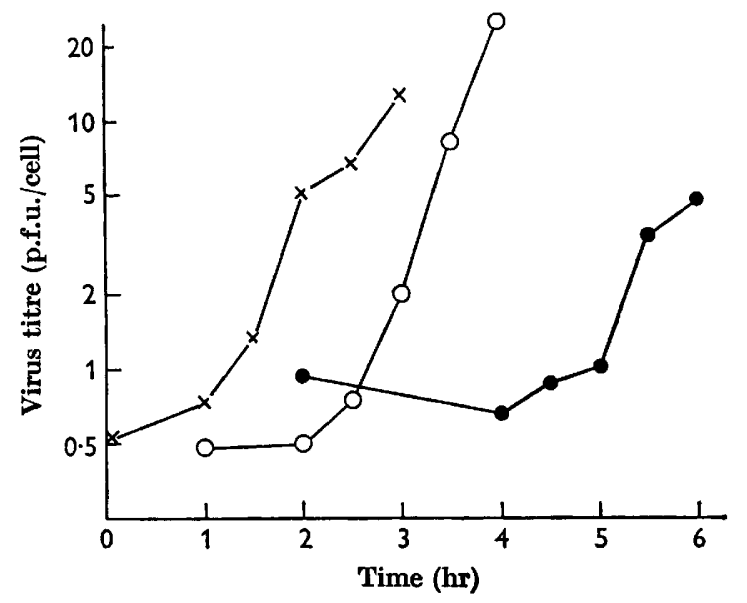

Fig. 5

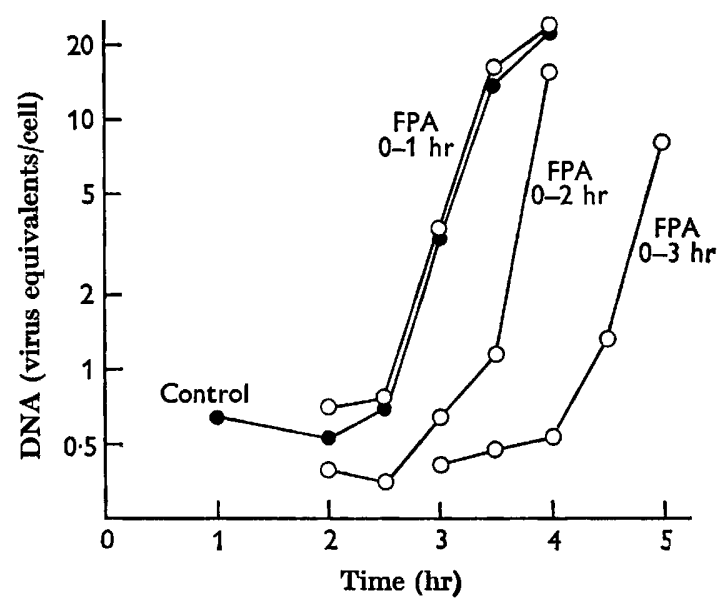

Fig. 6

Fig. 5. Effect of time of addition of FPA on its ability to inhibit the synthesis of viral DNA by infected cultures. The symbols $O, O$ and $x$ have the same meanings as in Fig. 4.

Fig. 6. Course of synthesis of viral DNA after temporary exposure of infected cultures to FPA. All points were obtained by titrating the virus yield at $24 \mathrm{hr}$ from cultures to which BDU was added at the times shown. 0 , normal cultures; $O$, cultures exposed to FPA for the first 1, 2 or $3 \mathrm{hr}$ after infection.

\section{DISCUSSION}

The ability of $p$-fluorophenylalanine (FPA) to inhibit viral DNA synthesis showed that the formation of new protein was essential for the development of viral DNA. Various experiments designed to time the necessary protein synthesis gave consistent results, and indicated that the process began about $1 \frac{1}{4} \mathrm{hr}$ after infection. In the interpretation of these experiments it was assumed that FPA began to act without appreciable delay when added to a culture and ceased to act as soon as it was removed. The assumption probably caused little error, for it is known that amino acids in the medium equilibrate rapidly with the amino acid pool of cells in culture (Eagle, 1959). Also, Wecker \& Schonne (1961) found that FPA was incorporated without detectable lag into the proteins of cultured chick embryo cells, and that incorporation ceased as soon as phenylalanine was added to the medium.

The effect of FPA on DNA synthesis was not due to interference with the initiation of infection, for even high concentrations of FPA allowed the formation of several soluble viral antigens. It is known that the growth of vaccinia virus causes increased activity of at least two enzymes (thymidine kinase, DNA polymerase), which is first detectable in cells about $2 \mathrm{hr}$ after infection (Green \& Pina, 1962; 
Magee, 1962; McAuslan \& Joklik, 1962; Kit, Piekarski \& Dubbs, 1963), and that the increase can be prevented by FPA or puromycin (McAuslan \& Joklik, 1962; Kit, Dubbs \& Piekarski, 1963). It is therefore likely that the inhibition of DNA synthesis by FPA in our experiments was due to interference with the formation of these or similar enzymes. Normal cell enzymes can participate in the formation of viral DNA, for Dubbs \& Kit (1964) found that a mutant of vaccinia, which was unable to induce thymidine kinase, incorporated tritiated thymidine into cytoplasmic foci when growing in $\mathrm{L}$ cells that did contain the enzyme. It is now apparent that the pre-existing cell enzymes on their own are unable to complete the synthesis of any viral DNA.

New enzymes might be formed under the influence of viral DNA or they might be cellular enzymes whose synthesis had been stimulated by infection. Recent evidence suggests the former possibility. Kit, Piekarski \& Dubbs (1963) showed that a subline of $\mathrm{L}$ cells lacking thymidine kinase nevertheless formed this enzyme when infected with vaccinia virus, and McAuslan (1963) found that the thymidine kinase induced by infection of HeLa cells with cowpox virus differed in heat stability and $\mathbf{K}_{\mathrm{m}}$ value from the enzyme of uninfected cells.

If the new enzymes were formed under the influence of viral DNA, they would have the antigenic specificity of virus rather than of host cell. Westwood, Zwartouw, Appleyard \& Titmuss (1965) found that ten of the soluble viral antigens formed during the growth of vaccinia virus were apparently not present in the virus particles, and suggested that these antigens might be enzymes concerned in virus synthesis. The first soluble antigens formed during the growth of rabbitpox virus in HeLa (ERK) cells appear between 1 and $1 \frac{1}{2} \mathrm{hr}$ after infection (Appleyard \& Westwood, 1964). The present estimate of $1 \frac{1}{4} \mathrm{hr}$ after infection for the start of the FPA-sensitive step in viral DNA synthesis agrees very well with this time. This suggests that some of the soluble viral antigens, particularly those formed early in virus growth, are enzymes required for viral DNA synthesis. If this conclusion be correct, it might be expected that FPA, at a concentration sufficient to prevent DNA synthesis, would also inhibit synthesis of the early viral antigens. The fact that this did not occur may be explained by the formation of altered proteins that, although non-functional due to their content of FPA, were antigenically indistinguishable from the active enzymes produced during normal virus growth.

We wish to thank Miss H. J. Way for her skilled technical assistance throughout this work.

\section{REFERENCES}

Appleyard, G. \& Westwood, J. C. N. (1964). The growth of rabbitpox virus in tissue culture. J. gen. Microbiol. 37, 391.

Cohen, G. N. \& Munier, R. (1959). Effets des analogues structuraux d'aminoacides sur la croissance, la synthèse de protéines et la synthèse d'enzymes chez Escherichia coli. Biochim. biophys. Acta, 31, 347.

DubBs, D. R. \& KrT, S. (1964). Isolation and properties of vaccinia mutants deficient in thymidine kinase-inducing activity. Virology, 22, 214.

EAGLE, H. (1959). Amino acid metabolism in mammalian cell cultures. Science, 130, 432.

Green, M. \& Pina, M. (1962). Stimulation of the DNA-synthesizing enzymes of cultured human cells by vaccinia virus infection. Virology, 17, 603. 
Kit, S., Durbs, D. R. \& Piekarski, L. J. (1963). Inhibitory effects of puromycin and fluorophenylalanine on induction of thymidine kinase by vaccinia-infected $L$ cells. Biochem. biophys. Res. Comm. 11, 176.

Kit, S., Piekarski, L. J. \& Dubbs, D. R. (1963). Induction of thymidine kinase by vaccinia-infected mouse fibroblasts. J. molec. Biol. 6, 22.

McAuslan, B. R. (1963). The induction and repression of thymidine kinase in the poxvirus-infected HeLa cell. Virology, 21, 383.

McAuslan, B. R. \& JokLIK, W. K. (1962). Stimulation of the thymidine phosphorylating system in HeLa cells on infection with pox virus. Biochem. biophys. Res. Comm. 8, 486.

MAGEE, W. E. (1962). DNA polymerase and deoxyribonucleotide kinase activities in cells infected with vaccinia virus. Virology, 17, 604.

WeCKer, E. \& SchonNe, E. (1961). Inhibition of viral RNA synthesis by parafluorophenylalanine. Proc. natn. Acad. Sci., U.S.A. 47, 278.

Westwood, J. C. N., Zwartouw, H. T., Appleyard, G. \& Trmmuss, D. H. J. (1965). Comparison of the soluble antigens and virus particle antigens of vaccinia virus. J. gen. Microbiol. 38, 47. 